\title{
KEDUDUKAN FATWA MAJELIS ULAMA INDONESIA (MUI) DALAM PERSPEKTIF HUKUM ISLAM DAN NASIONAL: STUDI IMPLIKASI FATWA TERHADAP MASYARAKAT
}

\author{
Imaro Sidqi \\ Institut Agama Islam Negeri Pekalongan, Jawa Tengah \\ Email: imarosidqi@gmail.com \\ Doli Witro \\ Institut Agama Islam Negeri Kerinci, Jambi \\ Email: doliwitro01@yahoo.com
}

\begin{abstract}
This article discusses the existence of MUI fatwa and its position in Indonesia. So far, people are more likely to use the fatwa law than national law. Many political interests, so that the independence of the fatwa in Indonesia, the MUI fatwa, is doubtful of its integrity. In the context of Islamic law, a fatwa is an essential presence in society, while in national law, a fatwa is only a doctrine whose status is not required to be followed. The deficient legal awareness of the community is a problem in the community because the political influence of the fatwa has a negative impact, so it is feared that it will create a negative thing that lives and develops into a civilization in society. From this writing, it can be concluded that the position of the fatwa is not required to be followed so that public awareness about the law must be socialized by the government so that people can understand. However, if the fatwa is following the constitution, the fatwa can be applied in the law so that the fatwa is not easy to be politicized by any party concerned.
\end{abstract}

Keywords: MUI Fatwa Position, Public Awareness, Fatwa Implications.

\section{A. Pendahuluan}

Dalam menjalani kehidupan, manusia tentunya saling membutuhkan satu sama lain. ${ }^{1}$ Saat ini, dengan adanya perkembangan zaman yang sangat pesat, kemungkinan akan memunculkan sebuah masalah baru. Disinilah hukum hadir dan terlihat eksistensinya di masyarakat. Hukum akan tampak dan dinilai baik atau buruk, sesuai atau tidak sesuai, berguna atau tidak berguna oleh masyarakat. Berangkat dari hal tersebut sudah semestinya hukum memberikan sebuah keadilan agar menciptakan ketertiban bagi masyarakat, karena keadilan menjadi landasan dasar untuk mencipatakan hukum positif yang bermartabat. ${ }^{2}$ Sehingga kondisi disuatu wilayah akan berjalan dengan lurus hingga berkembang dengan baik.

Negara Indonesia merupakan negara yang beragam, terlihat dari ahli fiqh, tafsir, sosial, dan bidang lainnya berelaborasi di dalam negeri ini untuk saling melengkapi antara satu dengan yang lain. Dalam keragaman itu pula, kemampuan manusia dalam memahami hukum Allah SWT semakin meningkat. Manusia juga diarahkan untuk meningkatkan kesadaran dalam berperilaku

1Doli Witro, "Praktek Jual Beli Parang dengan Cara Penumpukan untuk Meningkatkan Harga di Desa Koto Padang Perspektif Hukum Islam", Al-Qisthu, Vol. 17, No. 1, 2019, h. 34.

2 Yovita A. Mangesti dan Bernard L. Tanya, Moralitas Hukum, (Yogyakarta: Genta Publishing, 2014), h. 74. 
humanis, pluralis dan demokratis dalam keragaman ini. ${ }^{3}$ Selain itu respon ulama dalam hal ini merupakan kebutuhan yang penting bagi umat Islam dalam menghadapi sebuah permasalahan yang belum ada hukumnya. Respon tersebut dinamakan Fatwa. Fatwa disini berdiri atas kegigihan para cendikiawan muslim dalam berijitihad menemukan hukum untuk suatu permaslahan. Selain itu cendikiawan muslim juga memiliki peranan menyatukan gerak dan langkah umat Islam di dalam mewujudkan cita-cita bangsa dan negara. Dalam konteks ke-Indonesiaan para cendikiawan inilah yang menggerakan langkah untuk membentuk sebuah lembaga dalam merespon suatu permasalahan yang kontroversial di Indonesia, lembaga tersebut bernama Mejelis Ulama Indonesia ${ }^{4}$ (MUI) dan mengenai respon yang di munculkannya dinamakan Fatwa MUI.

Namun kemudian, tidak semua permasalahan yang tidak ada hukumnya akan dapat terselesaikan oleh fatwa. Dalam pasal 1 ayat 3 Undang-Undang Dasar Negara Republik Indonesia Tahun 1945 menyatakan bahwa Negara Indonesia merupakan Negara Hukum, hal ini membuktikan bahwa masyarakat dalam berkehidupan di negeri ini, harus bersandarkan dengan hukum utamanya ius constituntum (hukum yang saat ini berlaku) menjadi landasan penting oleh masyarakat. Akan tetapi, fakta yang terjadi di masyarakat banyak yang menjadikan fatwa sebagai landasan utama dan mengesampingkan hukum positif. Hal inilah, yang memicu sebuah kerancuan dalam sistem hukum di negeri ini.

Fatwa tersebut ditakutkan akan menjadi daya tarik politisi untuk dimanfaatkan ke arah yang salah. Kasus yang pernah terjadi pada pemilu tahun 2009 yang lalu, dimana masyarakat dihadapkan pada pemilihan anggota legislatif dan pemilihan presiden. Banyak masyarakat yang bergolongan putih (Golput) atau tidak memilih salah satu calon pada saat itu. Hal ini menimbulkan keresahan dikalangan aktivis partai politik. Keresahan ini dirasakan oleh PKS (Partai Keadilan Sejahtera) yang mendesak Majelis Ulama Indonesia (MUI) untuk mengeluarkan fatwanya, agar diharamkan bagi para masyarakat yang golput, dengan alasan akan menimbulkan mudharat dalam berdemokrasi. Pada akhirnya MUI mengeluarkan fatwa keharaman golput pada tanggal 13 Februari 2009. 5

Kemudian, fakta yang lainnya fatwa terhadap diskualifikasi terhadap Joko Widodo-Ma'ruf Amin kepada KPU pada pemilu tahun 2019 kemarin, menurut beberapa sebagian ulama mereka melakukan kecurangan dengan cara yang tidak konstitusional. Namun, fatwa tersebut ditolak oleh KPU dan oleh sebagian MUI. Lebih parahnya lagi fatwa yang dikeluarkan oleh FUUI (Forum Ulama Umat Indonesia) yang pada intinya bahwa fatwa tersebut mengharamkan memilih Joko Widodo-Ma'ruf Amin pada pemilu tahun 2019, kemudian fatwa ini dilegalkan oleh para kalangan ulama MUI, sehingga pada saat itu confuse people (membuat dilema masyarakat) dalam memilih para calonnya. Hal ini tentunya

${ }^{3}$ M. Ainul Yakin, Pendidikan Multikultural, (Semarang: Big Bang, 2008), h. 5.

4Selanjutnya kalimat Mejelis Ulama Indonesia dalam artikel ini disingkat dengan kata MUI saja. MUI didirikan pada tanggal 7 Rajab 1395 H, bertepatan dengan tanggal 26 Juli 1975 M di Jakarta. Lihat, Muhammad Maulana Hamzah, "Peran dan Pengaruh Fatwa MUI dalam Arus Transformasi Sosial Budaya di Indonesia", Millah: Jurnal Studi Agama, Vol. XVII, No. 1, 2017, h. 133.

5Detiknews, Pemilu 2009 Banyak Masalah, PKS Jabar Manut Fatwa Golput Haram, (Online), (https:/ / news.detik.com/berita-jawa-barat/d-1083763/, diakses pada 22 Mei 2020). 
bertentangan dengan fatwa keharaman golput yang dikeluarkan oleh MUI pada tahun 2009.6

Saat ini, kalangan masyarakat mempunyai kecenderungan untuk meletakkan fatwa sebagai dasar hukum. Hal ini terjadi karena ketidakfahaman masyarakat terhadap fatwa dan sumber hukum positif dalam sistem hukum nasional. Berangkat dari hal ini penulis tertarik untuk membahas secara komprehensif terhadap kedudukan fatwa MUI dan urgensitasnya bagi kalangan masyarakat yang dikaji dengan yuridis-normatif dalam konstitusional. Selain itu, tulisan ini akan membandingkan antara fatwa satu dengan fatwa yang lainnya yang kemudian akan dikembalikan kedudukannya dalam hukum positif di Indonesia. Sehingga tidak terjadi legal misunderstanding (kesalahpahaman hukum) dalam penerimaannya di masyarakat.

\section{B. Pembahasan}

\section{B.1. Kedudukan Fatwa di dalam Hukum Islam dan Hukum Nasional di Indonesia}

Fatwa menjadi landasan penting bagi umat Islam. Pada umumnya fatwa merupakan respon atau jawaban dari para ahli agama untuk menyesaikan permasalahan dalam hukum Islam. Fatwa berasal dari kata bahasa arab al-ifta, alfatwa yang berarti pemberian sebuah keputusan. Pemberian fatwa dari kalangan cendekiawan muslim ini, bukanlah sebuah keputusan yang terbilang gampang atau tidak memiliki landasan hukum yang jelas. Akan tetapi hukum fatwa ini, dibuat dengan konstruksi ilmu pengetahuan agama yang jelas.7 Allah SWT berfirman dalam QS. an-Nahl ayat 43 yang artinya:

"Dan Kami tidak mengutus sebelum engkau (Muhammad), melainkan orang laki-laki yang Kami beri wahyu kepada mereka; maka bertanyalah kepada orang yang mempunyai pengetahuan jika kamu tidak mengetahui."8 (QS. an-Nahl ayat 43).

Dalam ayat di atas menjelaskan anjuran bagi seseorang yang kurang berpengetahuan agama, untuk menanyakan sekaligus meminta solusi dalam permasalahan yang dihadapinya. Sehingga kedudukan hukum fatwa disini sangatlah penting. Hukum fatwa akan digunakan, ketika muncul sebuah masalah baru yang belum ada ketentuannya secara tegas, baik Al-Qur'an, AsSunnah dan Ijma' maupun pendapat-pendapat para fuqaha terdahulu. Maka disini fatwa merupakan sasaran masyarakat untuk memberikan arahan normatifnya terhadap gejala permasalahan hukum Islam. Karena kedudukannya yang begitu penting (urgent), orang-orang barat mengistilahkan fatwa sebagai yurisprudensi Islam. ${ }^{9}$

6Republika.co.id, Fatwa FUUI Haram Pilih Jokowi, MUI: Sah-Sah Saja, (Online), (https://www.republika.co.id/berita/dunia-islam/islam-nusantara/14/07/01/, diakses pada 22 Mei 2020).

${ }^{7}$ Ahyar A. Gayo, Kedudukan Fatwa MUI dalam Upaya Mendorong Pelaksanaan Ekonomi Syariah, (Jakarta: Laporan Akhir Penelitian Hukum Badan Pembinaan Hukum Nasional Kementerian Hukum dan HAM RI, 2011), h. 13. 272.

8Departemen Agama RI, Al-Qur'an dan Terjemahnya, (Bandung: Syaamil Qur'an, 2010), h.

${ }^{9}$ Ahmad Hatta, Tafsir Qur'an Perkata, (Jakarta: Maghfirah Pustaka, 2009), h. 272. Lihat juga, M. Erfan Riadi, “Kedudukan Fatwa Ditinjau Dari Hukum Islam dan Hukum Positif (Analisis Yuridis Normatif)", Ulumuddin, Vol. 7, No. 1, 2010, h. 472. 
Penggalian dasar hukum dari fatwa sendiri mengacu pada Al-Quran dan Hadis yang kemudian dielaborasi dengan ilmu ushul figh, menjadi sebuah petunjuk untuk menggali hukum-hukum yang abstrak. Metode ijtihad yang menjadi andalan para ulama untuk menyakinkan masyarakat terhadap hukum yang belum ada solusinya. Berbeda dengan kedudukan fatwa dalam hukum nasional sebagaimana yang dijelaskan dalam Undang-Undang Nomor 12 Tahun 2011 tentang pembentukan peraturan perundang-undangan menyatakan bahwa hierarki peraturan perundang-undangan dalam sistem hukum nasional di antaranya: Undang-Undang Dasar Negara Republik Indonesia Tahun 1945, Undang-Undang/Peraturan Pemerintah Pengganti Undang-Undang, Peraturan Pemerintah, Peraturan Presiden, Peraturan Daerah. Peraturan daerah meliputi: Peraturan Daerah Provinsi, Peraturan Daerah Kabupaten/Kota, dan Peraturan Desa/Peraturan yang setingkat. Sedangkan untuk sumber hukum formal yang berlaku di Indonesia ada lima, di antaranya: Undang-Undang, kebiasaan, yurisprudensi (putusan hukum), traktat, dan doktrin..$^{10}$

Fatwa merupakan pendapat para pakar/ulama/ahli hukum yang didapat melalui proses penggalian hukum yang disepakati guna menemukan kepastian hukum yang dijadikan sebagai salah satu petunjuk atau nasehat masyarakat muslim dalam menjalankan kehidupan berbangsa dan bernegara. Fatwa ini bersifat responsif, dinamis dan informatif. Dikatakan responsif karena adanya fatwa, sebuah tanggapan atas adanya persoalan-persoalan masyarakat yang belum ada aturan hukum pasti yang mengaturnya. Sebagaimana kaidah hukum yang dikemukakan oleh Ibn Qayyim al-Jauziyyah fatwa dikatakan dinamis karena tidak menutup kemungkinan bahwa fatwa itu akan berubah seiring dengan berubah dan berkembangnya waktu, tempat, keadaan, niat bahkan kebiasaan.11 Sedangkan fatwa dikatakan informatif karena fatwa bersifat memberi informasi yang menerangkan terkait permasalahan-permasalahan yang belum mendapatkan jalan keluar, sehingga fatwa disini berfungsi juga menjelaskan sesuatu yang dipertanyakan masyarakat muslim pada khususnya dan masyarakat Indonesia pada umunya.

Perlu diketahui bahwa keberlakuan fatwa tidak mengikat secara menyeluruh kepada seluruh masyarakat Indonesia. Sehingga pemaksaan tidak akan terjadi dalam konteks penerapan fatwa MUI bagi seluruh masyarakat Indonesia. Meskipun orang tersebut selaku peminta fatwa, tidak ada keharusan baginya untuk mengikuti ataupun menjalankan fatwa tersebut. Bisa dikatakan bahwa keberlakuan secara khusus kepada masyarakat muslim Indonesia karena dasar penggalian hukum yang digunakan lembaga pembuat fatwa MUI tidak terlepas bersumber dari Al-Quran dan Sunnah Rasulullah s.a.w. "Sebagaimana diketahui bahwa mayoritas masyarakat Indonesia beragama Islam", 12 orientasi tujuan hukum nasional negara ini adalah melindungi kehidupan seluruh Warga Negara Indonesia tanpa terkecuali. Dalam hal ini, keberlakuan hukum tetap berpegang pada keberagaman ras, agama, suku, dan budaya yang dimiliki

10M. Erfan Riadi, “Kedudukan Fatwa Ditinjau Dari Hukum Islam dan..., h. 474. Lihat juga, Titik Triwulan Tutik, Pengantar Ilmu Hukum, (Jakarta: Sinar Grafika, 2006), h. 136.

11Isa Ansori, "Kedudukan Fatwa di Beberapa Negara Muslim (Malaysia, Brunei Darussalam dan Mesir)", Analisis, Vol. 17, No. 1, 2017, h. 139.

12Doli Witro, "Ulama and Umara in Government of Indonesia: a Review Relations of Religion and State", Addin, Vol. 14, No. 1, 2020. 
Indonesia. ${ }^{13}$ Oleh karena itu, negara tidak mengakomodir fatwa MUI ke dalam hukum positif yang berlaku di Indonesia.

\section{B.2. Urgensitas Fatwa MUI di Kalangan Masyarakat}

Kemajemukan masyarakat Indonesia tumbuh beriringan dengan berkembangnya kemajuan teknologi yang sangat pesat. Pola penyampaian dan penerimaan informasi yang sangat cepat serta munculnya berbagai macam persoalan baru yang bersifat kompleks, baik itu menyangkut masalah keagamaan maupun non-keagamaan, seperti sosial kemasyarakatan menciptakan berbagai persoalan baru yang muncul terkadang belum ada peraturan perundang-undangan yang mengaturnya. Bahkan, tidak jarang timbul keraguan di kalangan masyarakat terkait jawaban-jawaban yang dilontarkan oleh segelintir orang. Apalagi jika pemberi jawaban tersebut dinilai kurang kompeten akan bidang persoalan tersebut. ${ }^{14}$ Segala sesuatu yang ada di muka bumi ini sesuai dengan kehendak Sang Maha Pencipta. Allah SWT menurunkan Al-Quran sebagai petunjuk hidup umat manusia, dan semua sudah diatur di dalamnya baik berkenaan dengan kehidupan dunia maupun akhirat. Al-Quran merupakan sumber dari segala sumber hukum. Oleh karena itu, di dalam proses penggalian hukum atau proses berijtihad akan mengacu pada Al-Quran. Selain itu, juga akan mengacu kepada Sunnah. Kedua sumber hukum tersebut mempunyai keterkaitan yang sangat erat. Sebagaimana sabda Rasulullah s.a.w. yang artinya: Al-Quran itu dalil, dalil yang bersifat mujmal (global). Sedangkan hadis adalah penjelasannya atau perinciannya" (HR. al-Bukhari dan Muslim). ${ }^{15}$

Perlu diketahui bahwa ada tiga indikasi mendasar yang terkadung di dalam hukum Allah SWT yaitu indikasi menemukan hukum Allah dengan cara tersurat, tersirat dan tersembunyi. Pertama secara tersurat, cara ini bisa dilakukan dengan menemukan hukum Allah yang terdapat di dalam lafaz AlQuran dengan cara melihat makna harfiah yang ada pada lafaz Al-Quran tersebut. Kedua secara tersirat. Cara yang kedua ini bisa dikatakan lebih susah daripada cara yang pertama, dikarenakan untuk menemukan hukum Allah yang tersirat seseorang harus jeli melihat petunjuk/isyarat yang ada pada suatu lafaz di dalam Al-Quran. Ketiga, secara tersembunyi, cara inilah yang paling sulit dan tidak bisa dilakukan oleh orang awam. Hal ini dilakukan ketika seseorang sudah melakukan cara pertama dan kedua namun belum bisa menemukan hukum Allah. Untuk cara ketiga ini bisa dilakukan dengan melihat isi kandungan suatu lafaz sehingga bisa diketahui maksud Allah ketika menetapkan suatu hukum. Serangkain proses yang dilaluipun cukup menyita banyak waktu, tenaga serta pikiran. Dimulai dari proses pengkajian, penelitian kemudian penggalian secara mendalam yang melibatkan berbagai metode yang sistematis disertai dengan

${ }^{13}$ Betria Zarpina Yanti dan Doli Witro, "Self Maturity and Tasamuh As a Resolution of Religious Conflicts", Intizar, Vol. 25, No. 2, 2019.

${ }^{14} \mathrm{Al}$ Fitri Johar, Kekuatan Hukum Fatwa Majelis Ulama Indonesia (Mui) Dari Perspektif Peraturan Perundang-Undangan Di Indonesia, Pengadilan Agama Ruteng, Nusa Tenggara Timur, (Online), (https:/ / badilag.mahkamahagung.go.id/artikel/, diakses pada 22 Mei 2020).

${ }_{15}$ Abu Abdillah bin Ahmad al-Anshary al-Qurthubi, al-Jami' Li Ahkamil Qur'an, (Kairo: Darul Katib al-'Arabiyah wat Tibaah wan Nasyr, 1964), h. 178. 
penerapan ilmu beberapa ilmu bantu yang terkait, seperti ilmu tafsir, balaghah, nahwu, sharaf, ushul figh, dan lain sebagainya. ${ }^{16}$

Masyarakat memerlukan adanya sebuah wadah yang terorganisir yang didalamnya terdapat para pakar/para ulama/para cendekiawan yang mempunyai strata ilmu pengetahuan yang tinggi, berwawasan luas serta peka terhadap realitas yang tumbuh di tengah-tengah masyarakat. Dengan penduduk yang mayoritas beragama Islam terbentuknya suatu lembaga yang bertugas membimbing, membina serta mengayomi kaum muslimin di Indonesia menjadi sebuah kebutuhan. Hal ini selaras dengan munculnya permasalahanpermasalahan kontemporer yang tidak menutup kemungkinan memicu adanya pro dan kontra di dalam pencarian jalan keluar akan permasalahanpermasalahan tersebut. ${ }^{17}$

Sudah sepatutnya menjadi kesadaran bersama untuk tidak membiarkan masyarakat senantiasa merasa bingung dan resah karena adanya pro dan kontra yang kerap terjadi ketika adanya permasalahan-permasalahan kontemporer. Bayangkan apabila di dunia ini tidak ada para ulama yang bersedia melakukan proses penggalian hukum yang mendalam terkait suatu persoalan yang terjadi di masyarakat, niscaya kebingungan, keresahan akan membelenggu khalayak luas. Kebenaran akan sebuah informasi menjadi salah satu kebutuhan dasar masyarakat yang kini hidup di era digital. Kebenaran itu bisa saja terkuak salah satunya dengan adanya fatwa.

Masyarakat membutuhkan adanya petunjuk dan bimbingan, kecepatan dan ketepatan respon para ulama pemberi fatwa atas pertanyaan-pertanyaan terkait isu yang tumbuh dan berkembang di kalangan masyarakat kini menjadi hal yang tak kalah penting. Untuk menemukan jalan keluar terkait permasalahan-permasalahan yang berkembang para ulama melakukan penggalian hukum dengan menggunakan metodologi yang sistematis dan teoriteori yang tegas, konsisten serta bertanggung jawab berdasarkan dalil-dalil yang kuat. Kemunculan fatwa secara tidak langsung mengkonkretkan ajaran Islam yakni dibuktikan dengan adanya penerapan dari sumber hukum Islam, yaitu AlQuran dan Sunnah. Selain itu dengan adanya kemunculan fatwa itu membuktikan bahwa umat manusia mengalami pola pikir yang dinamis, yang senantiasa mengikuti perkembangan zaman. Hal itu juga dapat diartikan bahwa umat manusia semakin maju. Fatwa juga merupakan salah satu cara umat manusia dalam rangka menyebarluaskan ajaran agama Islam. Tanpa adanya fatwa, ajaran agama Islam yang dianut oleh mayoritas masyarakat Indonesia akan mengalami stagnansi dikarenakan dianggap tidak mampu menjawab permasalahan-permasalahan yang berkembang di masa sekarang. Disinilah letak urgensitas fatwa di kalangan masyarakat.

Sebagaimana yang dikemukakan oleh Wahbah Zuhayli dalam kitab al-Figh al-Islamy wa Adillatuh, salah satu metode yang digunakan dalam berfatwa adalah yang pertama melakukan kajian terhadap nash-nash yang terdapat dalam alQuran dengan menggunakan disiplin ilmu yang berhubungan seperti seperti ilmu bahasa dengan memperhatikan beberapa kata di antaranya seperti kata

16Iffatul Umniati Ismail, “Telaah Kritis Metodologi Istinbath MUI (Studi Kasus Fatwa tentang Golput)", Media Syariah: Wahana Kajian Hukum Islam dan Pranata Sosial, Vol. 13, No. 1, 2011, h. 74 .

17Rohadi Abdul Fatah, Analisis Fatwa Keagamaan dalam Fikih Islam, (Jakarta: PT. Bumi Aksara, 2010), h. $87-88$ 
mujmal, musytarak, atau lafadz yang diragukan termasuk lafadz 'am atau khash, haqiqah atau majaz, haqiqah atau 'urf, muthlaq atau muqayyad, dan lain sebagainya. ${ }^{18}$ Ini baru masih terkait satu contoh penerapan ilmu yang dilakukan dalam rangka menemukan kepastian hukum dari isu-isu atau masalah-masalah kontemporer yang terjadi. Maka untuk bisa melakukan kajian terhadap nash, seseorang disyaratkan untuk mengetahui dan memahami Al-Quran meskipun tidak menyeluruh, namun ia mengetahui ayat-ayat hukum yang berjumlah sekitar 500 ayat menurut pendapat al-Ghazali yang telah disepakati oleh alQadhi Ibnu al-Arabi, ar-Razi, Ibnu Qudamah, dan al-Qarafi. Pendapat al-Ghazali ini juga dibantah oleh ulama lain sebagaimana yang dinukil dari Imam Abdullah bin Mubarak bahwa ada 900 jumlah ayat hukum. Tidak semua orang menguasai disiplin ilmu, teori-teori kebahasaan serta ayat-ayat hukum tersebut.

Hal di atas selaras dengan usulan Ibnu Qayyim yang menukil pendapat dari Imam Ahmad bahwa tidak ada kebolehan bagi seseorang yang akan berfatwa namun dirinya tidak mengetahui hal ihwal manusia atau apa yang terjadi disekitarnya. Apabila hal itu diabaikan, maka dikhawatirkan akan muncul fatwa-fatwa yang tidak terpakai karena dianggap tidak sesuai dengan culture atau budaya masyarakat setempat. Tentu untuk memenuhi persyaratan di atas bukanlah sesuatu yang mudah. Maka dari itu, posisi fatwa bagi umat Islam disini mempunyai peran yang sangat penting dalam kehidupan bernegara.

\section{B.3. Kontroversi Fatwa MUI pada Pemilu dan Implikasinya Kepada Masyarakat}

Negara Indonesia merupakan negara muslim terbesar di dunia dengan jumlah penduduk beragama Islam terbanyak. Hal ini menandakan bahwa kemajemukan negara ini, didominasi oleh umat Islam. Sehingga ketika terjadi suatu gejala sosial, maka solusi dari kalangan cendikiawan muslim yang selalu menjadi perhatian penting dalam berkehidupan bernegara. Jawaban ataupun respon tersebut bertujuan agar kemakmuran rakyat tercapai dengan optimal, karena pada hakikatnya manusia mempunyai 5 kebutuhan yang penting yaitu kebutuhan fisiologi, rasa aman, afiliasi, harga diri, dan pengembangan potensi. ${ }^{19}$

Fatwa merupakan respon dari kalangan ulama atas persoalan atau gejala sosial yang dihadapi oleh masyarakat. ${ }^{20}$ Kejelasan hukum fatwa, sangat penting bagi umat Islam yang mendominasi di negeri ini. Indonesia memiliki sekumpulan para ulama yang menjadi satu kesatuan berbentuk lembaga yaitu MUI yang bertugas memberikan jawaban-jawaban atas persoalan yang terjadi di dalam masyarakat. Disinilah eksistensi MUI mulai terlihat seiring berkembang dan kompleksnya permasalahan yang berkembang. Namun sayangnya, pengaruh politik yang tidak baik (negative) mulai bermunculan yang mempengaruhinya.

Politik dan hukum mempunyai jalinan hubungan yang sangat erat dan dapat menimbulkan kesewenang-wenangan kekuasaan, namun politik tanpa

${ }^{18}$ Faridatus Suhadak, "Urgensi Fatwa dalam Perkembangan Hukum Islam”, De Jure, Vol. 5, No. 2, 2013, h. 190.

19W. Poespoprodjo, Filsafat Moral, (Bandung: CV Pustaka Grafika, 1999), h. 142.

${ }^{20}$ Amir Syarifuddin, Ushul Fiqh Jilid II, (Jakarta: Kencana, 2008), h. 484. 
hukum akan menjadi kelumpuhan. ${ }^{21}$ Politisasi fatwa cenderung akan mengakibatkan keberpihakan kepada salah satu pihak yang kemudian akan menjadi bias di masyarakat. Hal inilah, yang kemudian menjadi kontroversikontoversi dari kalangan akademisi dan masyarakat pada umumnya. Disinilah fatwa mulai terkikis integritasnya seiring berkembangnya zaman.

Kasus yang pernah terjadi pada pemilu tahun 2009 yang lalu, dimana masyarakat dihadapkan pada pemilihan anggota legislatif dan pemilihan presiden. Banyak masyarakat yang bergolongan putih (Golput) pada saat itu. Hal ini menimbulkan keresahan dikalangan aktivis partai politik. Keresahan ini dirasakan oleh PKS (Partai Keadilan Sejahtera) yang mendesak Majelis Ulama Indonesia (MUI) untuk mengeluarkan fatwanya, agar diharamkan bagi para masyarakat yang golput, dengan alasan akan menimbulkan mudharat dalam berdemokrasi. Pada akhirnya MUI mengeluarkan fatwa keharaman golput pada tanggal 13 Februari 2009. Implikasi fatwa ini bagi masyarakat, secara tidak langsung memaksa masyarakat untuk memilih dalam Pemilihan Umum (pemilu). Implikasi dari hal terlihat pada pemilu tahun 2014 menjadi semakin berkurang masyarakat yang melakukan golput. Pada tahun 2009 tercatat 29,01 \% golput dan kemudian partisipasi pemilu tahun 2014 mencapai $75 \% .22$

Berbeda dengam fatwa yang dikeluarkan oleh FUUI (Forum Ulama Umat Indonesia) yang pada intinya bahwa fatwa tersebut mengharamkan memilih Joko Widodo-Ma'ruf Amin pada pemilu tahun 2019. Fatwa ini kemudian dianggap sah oleh MUI dalam konteks berlakunya hanya untuk kalangan FUUI saja, namun sejati MUI tidak berpihak kepada siapapun, sehingga pada saat itu confuse people (membuat dilema masyarakat) awam dalam memilih para calon presiden. ${ }^{23} \mathrm{Hal}$ ini tentunya bertentangan dengan fatwa keharaman golput yang dikeluarkan oleh MUI pada tahun 2009. Fatwa ini bukan berasal dari MUI, namun menjadi implikasi yang buruk bagi masyarakat. Tentunya sebagian masyarakat percaya atas kabar paslon yang tidak pantas menjadi Capres dan Cawapres pada tahun 2019, hal ini tentu menjadi kerugian atau ketidakadilan bagi salah satu paslon.

Pada hakikatnya fatwa hanya sebuah doktrin yang kedudukannya tidak wajib diikuti atau tidak mengikat bagi masyarakat Indonesia secara menyeluruh, namun doktrin bisa menjadi pertimbangan sebuah hukum jika tidak bertentangan dengan perundang-undangan. Dari kedua kasus tersebut membuktikan, bahwa sebenarnya peran MUI justru memberikan konstribusi yang baik bagi negara. Akan tetapi, karena derasnya politik praktis yang menyelimuti negeri ini menjadi fatwa dimanfaatkan oleh kalangan politik. Berbeda kasus dengan kedua, kasus tersebut bertentangan dengan hak-hak

${ }^{21}$ M. Mahfud MD, Pergulatan Politik dan Hukum di Indoenesia, (Yogyakarta: Grama Medika, 1999), h. 9-12.

22Detiknews, Dibanding Tahun 2009, Angka Golput Pemilu 2014 Lebih Rendah, (Online), (https:/ / news.detik.com/berita/2578828/, diakses pada 22 Mei 2020).

${ }^{23}$ Republika.co.id, Fatwa FUUI Haram Pilih Jokowi, MUI: Sah-Sah Saja, (Online), (https://www.republika.co.id/berita/dunia-islam/islam-nusantara/14/07/01/, diakses pada 22 Mei 2020). Tindak menjatuhkan lawan berpolitik dengan cara yang tidak benar, seperti melakukan ujaran kebencian, menghina, dan mencaci Caleg lain sehingga merusak nama baiknya di mata masyarakat dapat dikenakan sanksi hukum. Lihat, Doli Witro, "Peaceful Campaign In Election Al-Hujurat Verse 11 Perspective", Alfuad: Jurnal Sosial Keagamaan, Vol. 3, No. 2, 2019, h. 16. 
memilih dan dipilih dalam konstitusi, sehingga keberlakuan fatwa yang bertentangan dengan konstitusi tidak diperbolehkan untuk diikuti.

Jadi, kedudukan fatwa dalam hukum positif di Indonesia hanya sebatas doktrin yang tidak wajib diikuti, namun jika fatwa yang dikeluarkan oleh MUI tidak bertentangan secara konstitusional dan membawa manfaat yang baik, makam wajib untuk diikuti dengan diberikan payung hukum oleh negara. Kedua kasus ini mencerminkan baik dan buruknya fatwa serta implikasinya dalam masyarakat.

\section{B.4. Pandangan masyarakat terhadap Fatwa MUI}

Berbicara tentang pandangan itu artinya akan dibahas sesuatu yang kompeks. Dikatakan kompleks karena pandangan merupakan hasil perbuatan memandang yang dilakukan oleh seseorang atau sekelompok orang yang sebelumnya telah melalui proses melihat, memperhatikan, mencari tahu, sampai akhirnya terdapat pada satu titik akhir hasil analisa yakni berupa kesimpulan akan suatu hal. Keberagaman dalam konteks pandangan masyarakat tentu sudah menjadi sesuatu yang dapat dipastikan keberadaannya. Antara orang satu dengan yang lainnya pasti memiliki cara pandang yang berbeda-beda yang akan berdampak pada hasil pandangan yang berbeda pula. Hal ini juga berlaku untuk masyarakat Indonesia.

Sebagaimana diketahui bahwa masyarakat Indonesia adalah masyarakat yang pluralis. Masyarakat dengan ciri keragamannya. Mulai dari ragam budaya, ras, suku, bahasa, kepercayaan bahkan agama yang diakui di tengah-tengah masyarakat. Dengan latar belakang keragaman tersebut, maka tidak dapat dipungkiri bahwa mengenai pandangan masyarakat terhadap fatwa MUI juga mengalami keberagaman. Ada segolongan masyarakat yang menyetujui dikeluarkannya suatu fatwa dari MUI ada pula yang tidak menyetujuinya. Ada yang merespon dengan baik, ada yang merespon dengan kurang baik, dan bahkan ada yang mengabaikan atau tidak merespon sama sekali. Merespon dengan baik, bisa diartikan bahwa seseorang mneyetujui fatwa yang dikeluarkan MUI dan menerapkan serta mengikuti fatwa tersebut di dalam kehidupan bernegaranya. Merespon dengan kurang baik, bisa dikatakan bahwa misalnya seseorang menyetujui fatwa MUI namun dalam pengaplikasiannya fatwa tersebut tidak digunakan. Sedangkan yang mengabaikan fatwa MUI, artinya seseorang tidak memperdulikan adanya suatu fatwa yang dimunculkan (acuh tak acuh). 24

Keberagaman terhadap kemunculan fatwa inilah yang kemudian menimbulkan adanya pro dan kontra. Beberapa fatwa MUI yang menimbulkan banyak pro dan kontra diantaranya fatwa tentang pengharaman golput (golongan putih), pengharaman rokok, dan pengharaman BPJS. ${ }^{25}$ Ada yang berpendapat bahwa keputusan MUI tersebut menunjukkan sikap keberanian MUI karena telah mengeluarkan fatwa tersebut dan itu dinilai sebagai bentuk responsif yang baik dari MUI selaku lembaga yang diberi kewenangan untuk

24Riza Hadi Kusuma dan Yoyok Sabar Waluyo, "Sikap dan Pandangan Masyarakat Terhadap Fatwa-Fatwa Majelis Ulama Indonesia (MUI) (Studi Kasus Pada Civitas Akademika Politeknik Negeri Jakarta), Epigram, Vol. 7, No. 1, 2010, h. 4.

25Merdeka.com, 4 Fatwa MUI yang bikin heboh, (Online), (https:/ / www.merdeka.com/peristiwa/, diakses pada 22 Mei 2020). 
mengeluarkan fatwa baik yang berhubungan dengan sosial keagamaan maupun sosial kemasyarakatan. Ada juga yang berpendapat bahwa fatwa yang dikeluarkan MUI itu bukanlah sebuah keputusan yang bijak. Dalam hal ini misalnya tentang pengharaman rokok. Dalam pandangan sebagian masyarakat yang takut dengan adanya pengharaman rokok karena orang-orang tersebut takut akan kehilangan pekerjaannya.

Perlu diketahui oleh masyarakat bahwa di zaman modern seperti saat ini fatwa kerap muncul dengan berbagai penyimpangan. Beberapa penyimpangan yang ada diantaranya: Pertama, yaitu mengesampingkan apa yang terkandung di dalam sumber hukum utama Islam (Al-Quran dan Sunnah) maupun sumber hukum lain seperti ijma, qiyas, dan lain-lain. Padahal itu merupakan dasar yang harus dipegang oleh setiap pembuat fatwa. Bisa dipastikan bahwa fatwa yang tidak bersumber dari Al-Quran dan Sunnah tidak dapat dijadikan rekomendasi jalan keluar terhadap suatu permasalahan. Kedua, yaitu salah pemahaman terhadap nash, yang dalam hal ini dengan sengaja dilakukan sehingga terjadi kesalahan dalam proses melakukan interpretasi.

Pada dasarnya, memang tidak ada aturan yang mengikat mengenai keharusan menjalankan atau mengikuti sebagaimana yang difatwakan oleh MUI (Majelis Ulama Indonesia). Semua orang berhak menentukan pilihannya masingmasing untuk mengikuti fakta tersebut ataupun tidak. Negara tidak akan memberikan hukuman bagi masyarakat yang tidak mengikui fatwa yang dikeluarkan MUI. Karena itu memang tidak diatur secara resmi di dalam hukum positif Indonesia. Namun yang perlu diketahui bahwa, kemunculan fatwa MUI ini tidak serta merta dikarenakan suatu wewenang MUI saja melainkan sebuah proses penggalian hukum untuk menemukan kepastian hukum dari adanya permasalahan-permasalahan kontemporer yang berkembang di lingkungan masyarakat namun belum ada aturan hukum yang jelas mengaturnya. Dikeluarkannya fatwa ini diharapkan mampu menjadi pemandu masyarakat ketika menghadapi suatu permasalahan kontemporer atau bisa juga dikatakan fatwa ini mampu membrikan jalan keluar bagi masyarakat.

\section{Simpulan}

Kedudukan fatwa dalam pandangan Hukum Islam sangatlah penting, karena permasalahan maupun persoalan yang dihadapi masyarakat begitu kompleks. Sehingga gejala sosial yang di masyarakat terselesaikan bisa terselesaikan dengan adanya fatwa. Berbeda halnya dengan kedudukan fatwa menurut hukum nasional, posisi fatwa disini kurang diperhatikan atau tidak diakui eksistensinya, karena statusnya tidak wajib untuk diikuti. Mayoritas penduduk Indonesia merupakan orang-orang muslim. Umat muslim menganggap bahwa keberadaan fatwa sangat penting baginya. Implikasi fatwa terhadap masyarakat sangat jelas, hal ini bisa dilihat dari kecenderungan menggunakan fatwa daripada hukum nasional dalam kehidupan bernegara. Desain grafis negara ini, semuanya tercover dalam konstitusi yang kemudian semua peraturan yang di bawahnya harus sesuai secara konstitusional. Inilah alasan hukum fatwa kurang diperhatikan keberadaannya, karena dimata konstitusi fatwa hanyalah sebuah doktrin yang tidak wajib diikuti. Namun fatwa dapat menjadi sebuah pertimbangan hukum dalam pembuatan undang-undang, karena esensinya yang begitu dipercaya oleh umat Islam. Sehingga pembuat 
undang-undang memilah fatwa MUI yang sesuai dengan ideologi bangsa dan konstitusi agar tidak bertentangan dengannya. Jadi, kasus-kasus kontroversial yang terjadi haruslah dikembalikan sesuai dengan desain peraturan negara ini. Jika kasus yang sesuai dengan konstitusi negra maka dapat diberikan payung hukum dengan ditanamkan nilai-nilai konstitusi di perundang-undangan. Kemudian jika tidak sesuai dengan konstitusi negara maka tidak dibolehkan untuk mengikutinya.

\section{Referensi:}

al-Qurthubi, Abu bin Ahmad al-Anshary, 1964, al-Jami' Li Ahkamil Qur'an, Kairo: Darul Katib al-'Arabiyah wat Tibaah wan Nasyr.

Ansori, Isa, 2017, “Kedudukan Fatwa di Beberapa Negara Muslim (Malaysia, Brunei Darussalam dan Mesir)", Analisis, Vol. 17, No. 1.

Departemen Agama RI, 2010, Al-Qur'an dan Terjemahnya, Bandung: Syaamil Qur'an.

Detiknews, Dibanding Tahun 2009, Angka Golput Pemilu 2014 Lebih Rendah, (Online), (https://news.detik.com/berita/2578828/, diakses pada 22 Mei 2020).

Detiknews, Pemilu 2009 Banyak Masalah, PKS Jabar Manut Fatwa Golput Haram, (Online), (https://news.detik.com/berita-jawa-barat/d-1083763/, diakses pada 22 Mei 2020).

Fatah, Rohadi Abdul, 2010, Analisis Fatwa Keagamaan dalam Fikih Islam, Jakarta: PT. Bumi Aksara.

Gayo, Ahyar A., 2011, Kedudukan Fatwa MUI dalam Upaya Mendorong Pelaksanaan Ekonomi Syariah, Jakarta: Laporan Akhir Penelitian Hukum Badan Pembinaan Hukum Nasional Kementerian Hukum dan HAM RI.

Hamzah, Muhammad Maulana, 2017, “Peran dan Pengaruh Fatwa MUI dalam Arus Transformasi Sosial Budaya di Indonesia", Millah: Jurnal Studi Agama, Vol. XVII, No. 1.

Hatta, Ahmad, 2009, Tafsir Qur'an Perkata, Jakarta: Maghfirah Pustaka.

Ismail, Iffatul Umniati, 2011, “Telaah Kritis Metodologi Istinbath MUI (Studi Kasus Fatwa tentang Golput)", Media Syariah: Wahana Kajian Hukum Islam dan Pranata Sosial, Vol. 13, No. 1.

Johar, Al Fitri, Kekuatan Hukum Fatwa Majelis Ulama Indonesia (Mui) Dari Perspektif Peraturan Perundang-Undangan Di Indonesia, Pengadilan Agama Ruteng, Nusa Tenggara Timur, (Online), (https://badilag.mahkamahagung.go.id/artikel/, diakses pada 22 Mei 2020).

Kusuma, Riza Hadi dan Yoyok Sabar Waluyo, 2010, “Sikap dan Pandangan Masyarakat Terhadap Fatwa-Fatwa Majelis Ulama Indonesia (MUI) (Studi Kasus Pada Civitas Akademika Politeknik Negeri Jakarta), Epigram, Vol. 7, No. 1.

Mahfud MD, M., 1999, Pergulatan Politik dan Hukum di Indoenesia, Yogyakarta: Grama Medika.

Mangesti, Yovita A. dan Bernard L. Tanya, 2014, Moralitas Hukum, Yogyakarta: Genta Publishing.

Merdeka.com, 4 Fatwa MUI yang bikin heboh, (Online), (https:/ /www.merdeka.com/peristiwa/, diakses pada 22 Mei 2020). 
Poespoprodjo, W., 1999, Filsafat Moral, Bandung: CV Pustaka Grafika.

Republika.co.id, Fatwa FUUI Haram Pilih Jokowi, MUI: Sah-Sah Saja, (Online), (https://www.republika.co.id/berita/dunia-islam/islamnusantara/14/07/01/, diakses pada 22 Mei 2020).

Riadi, M. Erfan, 2010, “Kedudukan Fatwa Ditinjau Dari Hukum Islam dan Hukum Positif (Analisis Yuridis Normatif)", Ulumuddin, Vol. 7, No. 1.

Suhadak, Faridatus, 2013, "Urgensi Fatwa dalam Perkembangan Hukum Islam", De Jure, Vol. 5, No. 2.

Syarifuddin, Amir, 2008, Ushul Fiqh Jilid II, Jakarta: Kencana.

Tutik, Titik Triwulan, 2006, Pengantar Ilmu Hukum, Jakarta: Sinar Grafika.

Witro, Doli, 2019, "Peaceful Campaign In Election Al-Hujurat Verse 11 Perspective", Alfuad: Jurnal Sosial Keagamaan, Vol. 3, No. 2.

Witro, Doli, 2019, "Praktek Jual Beli Parang dengan Cara Penumpukan untuk Meningkatkan Harga di Desa Koto Padang Perspektif Hukum Islam", AlQisthu, Vol. 17, No. 1.

Witro, Doli, 2020, "Ulama and Umara in Government of Indonesia: a Review Relations of Religion and State", Addin, Vol. 14, No. 1, 2020.

Yakin, M. Ainul, 2008, Pendidikan Multikultural, Semarang: Big Bang.

Yanti, Betria Zarpina dan Doli Witro, 2019, "Self Maturity and Tasamuh As a Resolution of Religious Conflicts", Intizar, Vol. 25, No. 2. 